\title{
KŁOPOTY UCHODŹCÓW CZY KŁOPOTY Z UCHODŹCAMI? DIPISI NA ŁAMACH „DZIENNIKA POLSKIEGO I DZIENNIKA ŻOŁNIERZA" W LATACH 1945-1948
}

\author{
Tomasz Korban
}

D http://orcid.org/0000-0001-8782-1677

Uniwersytet Pedagogiczny

im. Komisji Edukacji Narodowej w Krakowie

\author{
ABSTRACT \\ REFUGEES' TROUBLES OR TROUBLE WITH REFUGEES? \\ THE DPS AS FEATURED IN THE POLISH DAILY \& SOLDIER'S DAILY \\ BETWEEN 1945 AND 1948
}

The article presents issue of the Polish displaced persons on the territory of the former Third Reich in light of coverage in the The Polish Daily \& Soldier's Daily newspaper (Dziennik Polski $i$ Dziennik Żotnierza - DPDŻ). The author of this article verifies this journalistic representation, which wasn't in line with reality. Journalists wrote about such topics as material conditions in the DP camps, possibilities of cultural activities in camps and attitudes of camp authorities towards the DPs. The newspaper criticised the UNRRA which it regarded as a proponent of compulsory repatriation. This and other opinions have been confronted with the actual state of research. Another question raised by the newspaper was one concerning the international efforts taken to solve problem of the displaced persons. DPDŻ's journalists were against Moscow and its satellites states, which sought to repatriate all the DPs.

Keywords: DPs, repatriation, UNRRA, IRO, The Polish Daily \& Soldier's Daily.

Słowa kluczowe: dipisi, repatriacja, UNRRA, IRO, „Dziennik Polski i Dziennik Żołnierza”.

W chwili zakończenia II wojny światowej w Europie było ponad $11 \mathrm{mln}$ displaced persons, a prawie 2 mln spośród tej ogromnej zbiorowości miało polskie korzenie ${ }^{1}$. Problem uchodźstwa wojennego i powojennego nie był czymś nowym, jednak

${ }^{1}$ P. Sękowski, Activity of the International Community in Europe after the Second World War within the Scope of the International Refugee Organization as a Model of the Aid Action Towards Refugees, „Securitologia” 2017, no. 1, s. 121.

Adres do korespondencji: tomek.korban@gmail.com 
skala tego zjawiska spowodowała, że stał się on jednym z najważniejszych zmartwień powstającego z gruzów wojny świata ${ }^{2}$. Milionowe rzesze uchodźców i dipisów wymagały podjęcia działań na masową i międzynarodową skalę, dlatego też kwestia ta znalazła się w zakresie działalności organizacji powstałej jeszcze w 1943 roku, z inicjatywy Sprzymierzonych - United Nations Relief and Rehabilitation Administration (UNRRA). Naczelne Dowództwo Sojuszniczych Sił Ekspedycyjnych (SHAEF) wypracowało również $\mathrm{w}$ tym zakresie definicję displaced persons. Przede wszystkim alianci dokonali wyraźnego rozróżnienia pomiędzy uchodźcami a dipisami. Do tych ostatnich zaliczano osoby, które „w wyniku wojny znalazły się poza swoim państwem i chcą albo wrócić do kraju, albo znaleźć nową ojczyznę, lecz bez pomocy uczynić tego nie mogą, ponadto znaleźli się na terytorium innego kraju w wyniku działalności państw osi”’3. W rozwinięciu definicji sprecyzowano, że chodzi o uciekinierów wojennych lub politycznych, więźniów obozów koncentracyjnych, przymusowych lub dobrowolnych robotników, byłych jeńców wojennych i bezpaństwowców. Aby dostrzec różnicę pomiędzy przedstawieniem dipisów na łamach „Dziennika Polskiego i Dziennika Żołnierza" (DPDŻ) a stanem rzeczywistym, warto podkreślić znaczenie zapisu mówiącego, że te osoby mają być „tymczasowo zgrupowane na nieprzyjacielskim lub byłym nieprzyjacielskim terytorium"4. Dipisi byli więc ludźmi, którzy przymusowo znaleźli się na terytorium państw osi i mieli powrócić do kraju ojczystego, w odróżnieniu od uchodźców, którzy - jak głosiły późniejsze definicje - sami podejmowali decyzję o opuszczeniu kraju pochodzenia ${ }^{5}$. Tytuł dipisa dawał formalnie możliwość otrzymania opieki i dachu nad głową ${ }^{6}$, co miało umożliwić powrót do normalnego życia po okresie okupacji. Należy zaznaczyć, że z punktu widzenia humanitarnego każde z powyższych określeń wskazuje na przymusowy charakter emigracji i, jak pokazuje los wielu dipisów czy emigrantów, nie ma znaczenia, jaka klasyfikacja zostałaby przyjęta.

Zagadnieniu dipisów i uchodźców poświęcono wiele miejsca na łamach emigracyjnej prasy. Najwięcej badań w tym zakresie poczyniła Jolanta Chwastyk-Kowalczyk, której prace dotyczą również historii samego „Dziennika”7. Na terenie okupowanych Niemiec także nie brak poświęconych samej prasie dipisowskiej pozycji, które w znacznej mierze oddają rzeczywiste nastroje panujące wśród samych wysiedleńców ${ }^{8}$. Autorka monografii na temat londyńskiej gazety zdaje się jednak

2 J. Łaptos, Humanitaryzm i polityka. Pomoc UNRRA dla Polski i polskich uchodźców w latach 1944-1947, Kraków 2018, s. 97.

${ }^{3}$ Cytat za: A. Lembek, K. Wessels, Wyzwoleni, ale nie wolni. Polskie miasto w okupowanych Niemczech, Warszawa 2006, thum. B. Ostrow ska, s. 9; Por. P. S ęk ow ski, op. cit., s. 121.

${ }^{4}$ J. Łaptos, op. cit., s. 101-102.

${ }_{5}^{5}$ Por. P. Sęk ow ski, op. cit., s. 121-122.

${ }^{6}$ J. Łaptos, op. cit., s. 98.

7 J. Chwastyk-Kowalczyk, Londyński „Dziennik Polski i Dziennik Żolnierza” 1944-1989. Gazeta codzienna jako środek przekazu komunikatów kulturowych, Kielce 2008; eadem, Katyń, dipisi, PKPR na łamach polskich czasopism uchodźczych, Kielce 2011.

${ }^{8} \mathrm{~J}$. Ża k, Polscy dipisi w zachodnich strefach okupacyjnych Niemiec na łamach polskiej prasy emigracyjnej (1945-1947), „Naukowy Przegląd Dziennikarski” 2017, nr 3, s. 95-127. 
podzielać poglądy redaktorów gazety co do obrazu życia dipisów ${ }^{9}$. Nie jest to jednak wyobrażenie zgodne z rzeczywistością. Dlatego też głównym celem niniejszej pracy będzie przedstawienie i skonfrontowanie obrazu dipisów na łamach londyńskiej gazety z dotychczasowym stanem badań nad displaced persons.

Emigracyjne czasopismo „Dziennik Polski i Dziennik Żołnierza” (DPDŻ) powstało w 1944 roku w wyniku połączenia „Dziennika Polskiego”, oficjalnego organu prasowego rządu RP na wychodźstwie, i „Dziennika Żołnierza” - pisma 10 Brygady Kawalerii Pancernej. Gazeta bardzo szybko osiągnęła popularność i po wojnie stała się największym polskim dziennikiem na Wyspach Brytyjskich. Od początku czasopismo wspierało uchodźczy rząd, a także miało silnie antykomunistyczny profil. DPDŻ, choć w zmienionej formie, ukazywał się do lipca $2015 \mathrm{roku}^{10}$. Materiał źródłowy londyńskiej gazety do omawianego tematu obejmuje opinie redakcji, artykuły informacyjne, w tym oparte na korespondencji własnej redakcji, a także niezwykle ważne listy do redakcji, których autorami często byli sami dipisi, oraz streszczenia artykułów prasy zagranicznej zawierające odniesienia do sytuacji tych osób.

W niniejszym tekście autor pragnie skupić się na bezpośrednim okresie powojennym. Pierwsza cezura czasowa, rok 1945, jest podyktowana faktem, że w tym roku problem dipisów pojawił się po raz pierwszy na szeroką skalę na łamach „Dziennika", wraz z postępami wojsk sprzymierzonych, wkraczających na tereny III Rzeszy. Końcowa cezura natomiast, rok 1948, odnosi się do tego, że w poprzednim roku opiekę nad dipisami, którzy odrzucali repatriację, przejęła nowo powstała International Refugee Organisation (IRO) ${ }^{11}$. W artykułach DPDŻ widoczna jest pewna zmiana oceny tej organizacji, jeżeli porówna się ją z UNRRA.

Głównym obiektem zainteresowania redakcji pisma były losy polskich dipisów: sytuacja bytowa, repatriacja, emigracja, jak również polityka władz w Warszawie. Jednak na łamach „Dziennika” kwestię displaced persons poruszano także w szerszym kontekście działań UNRRA, a następnie IRO. Bezpośredni okres powojenny był czasem, w którym o uchodźcach i dipisach pisano najwięcej. Tematyka polskich wysiedleńców była obecna na łamach DPDŻ aż do 1960 roku, kiedy to „Dziennik” informował czytelników o ostatnim transporcie 50 polskich dzieci sprowadzonych z obozów w Niemczech Zachodnich do Wielkiej Brytanii ${ }^{12}$.

Pierwszym zagadnieniem, na które warto zwrócić uwagę, jest język używany przez redakcję „Dziennika”. Na jego łamach terminy: „dipis”, „uchodźca”, ,,wysiedleniec”, „przesiedleniec”, a nawet „emigrant” - były synonimami ${ }^{13}$. Miało to pewien wpływ na opisywanie sytuacji dipisów i niezrozumienie kroków podejmowanych przez UNRRA, a później IRO, które inaczej traktowały dipisów, a inaczej uchodźców. Dla sprawiedliwości warto jednak dodać, że ta kategoryzacja nie była obca

\footnotetext{
9 Przykłady: J. Chwastyk-Kowalczyk, Londyński „,Dziennik Polski i Dziennik Żotnierza”..., s. $108,116,225-226$.

${ }^{10}$ Katalog Biblioteki Narodowej; obecnie ukazuje się tylko „Tydzień Polski”, niegdysiejszy dodatek do „Dziennika”.

${ }^{11}$ P. Sękowski, op. cit., s. 123.

12 J. Chw as ty k-Kow a lczy k, Londyński ,Dziennik Polski i Dziennik Żotnierza” ..., s. 108.

13 DPDŻ, 813 emigrantów odptynęto do U.S.A., 29 X 1948.
} 
redakcji, ponieważ gazeta informowała o mającej miejsce w kwietniu 1946 roku konferencji w Londynie, na której wyraźnie podkreślono ten podział ${ }^{14}$; mimo to nie był on stosowany w czasopiśmie.

Zagadnieniem, które zostało najszerzej omówione na łamach czasopisma, była sytuacja polskich dipisów na ternie okupowanych Niemiec. Było to naturalne ponieważ tam znajdowało się ich najwięcej. Wynikało to również z informowania czytelników „Dziennika” o tragicznym - zdaniem dziennikarzy - losie rodaków. W szczególności temat ten obejmował następujące aspekty: sytuacja bytowa Polaków w obozach, sposób traktowania ich przez władze obozowe i okupacyjne, jak również porównywanie stosunku tychże władz do poszczególnych narodowości.

Przede wszystkim DPDŻ alarmował o złym stanie obozów, w których przebywali Polacy. Zakres problemów był bardzo szeroki: od podstawowych braków w żywności, odzieży, środkach czystości i infrastrukturze sanitarnej po dotkliwe warunki informowano na przykład o tym, że dipisi musieli spać na gołej ziemi ${ }^{15}$. Brak odpowiedniej żywności skutkował między innymi niską wydajnością pracy Polaków ${ }^{16}$. Władze okupacyjne zachęcały bowiem dipisów do pracy na rzecz swoich obozów, administracji i UNRRA. Niektóre polskie organizacje emigracyjne wprowadzały nawet obowiązek pracy ${ }^{17}$. Szczególnie negatywnie na dipisów działało lokowanie obozów UNRRA na terytoriach byłych niemieckich obozów koncentracyjnych czy zatrudnianie Niemców w policji obozowej. Co więcej, miało to wpływać demoralizująco na dipisów ${ }^{18}$. Po lekturze „Dziennika” można zresztą odnieść wrażenie, że obozy dla displaced persons niewiele różniły się od obozów koncentracyjnych. W rzeczywistości obozy dla dipisów nie zastępowały prawdziwego domu, ale nie były też tak złe, jak opisywał to DPDŻ. Twierdzenie, jakoby obozy dla dipisów przypominały obozy koncentracyjne, było nie tylko przesadą, ale nawet manipulacją, zwłaszcza jeżeli weźmie się pod uwagę cały wachlarz zbrodni i sposób traktowania więźniów przez Niemców w czasie wojny. Być może użycie takich sformułowań miało służyć zwróceniu uwagi na złe warunki mieszkalne, jakie panowały w niektórych obozach dla dipisów. Mimo to dla wielu wysiedleńców obozowe baraki były miejscem powrotu do normalnego życia ${ }^{19}$.

W zmianie negatywnego obrazu nie pomogła jednak autorefleksja redakcji gazety, która stwierdziła jeszcze na początku omawianego okresu, bo w czerwcu 1945 roku, iż: „Szereg artykułów, które ukazały się w ostatnich czasach na łamach Dziennika Polskiego prowadzić mogą do wniosku, że warunki życia w obozach dla Polaków w Niemczech przedstawiają obraz rozpaczliwy i dają przykład daleko

${ }_{14}$ DPDŻ, Przyszłość uchodźców w Europie. Obrady konferencji 20 państw, 9 IV 1946.

15 DPDŻ, Ciagłe wędrówki polskich wysiedleńców, 9 X 1945; DPDŻ, Straszliwe położenie Polaków $w$ amerykańskiej strefie okupacyjnej, 6 VII 1945.

16 DPDŻ, Złe odżywianie uchodźców powoduje niezdolność do pracy, $26 \mathrm{~V} 1948$.

17 J. Żak, op. cit., s. 104.

${ }^{18}$ DPDŻ, Jak Amerykanie w Niemczech traktuja Niemców, a jak Polaków?, 17 VIII 1945; DPDŻ, Błędy opieki nad wysiedleńcami, 6 X 1945; DPDŻ, Bandyci w mundurach rewidują obóz D.P., 26 VIII 1947.

19 J. Łaptos, op. cit., s. 217. 
posuniętej dezorganizacji i zaniedbania. Wniosek taki byłby jednak przesadzony"20. Dziennikarze w dalszej części tłumaczyli również wymowę swoich artykułów w ten sposób, że zwykle w pierwszej kolejności zwraca się uwagę na złe warunki. Z drugiej strony natomiast przyznawali, że w czasie od przygotowania reportażu do jego publikacji dany problem często ulegał rozwiązaniu. Redakcja za raportami polskich oficerów łącznikowych powtarzała również, że istnieją też „dobre” obozy, w których warunki są zbliżone do normalnych. Ponadto dziennikarze mieli świadomość, że warunki życia w obozie są zmienne, a poprawa następuje, ale powoli ${ }^{21}$. Niewielka liczba pozytywnych odniesień „Dziennika” do warunków bytowych w obozach objętych działaniami UNRRY nie zmienia jednak ogólnego ich obrazu ukazanego na łamach pisma.

Podobnej ocenie redakcji podlegały również życie kulturalne w obozach oraz prawa, jakie mieli dipisi do uczestniczenia w nim. Warto podkreślić, że po okresie niewoli i okupacji dla wielu dipisów potrzeba obcowania z językiem ojczystym była niemal równorzędna $\mathrm{z}$ podstawowymi potrzebami egzystencjalnymi ${ }^{22}$. W tym zakresie „Dziennik” informował o brakach polskojęzycznej literatury w bibliotekach obozowych. $\mathrm{Z}$ jednej strony wynikało to $\mathrm{z}$ obiektywnych problemów, $\mathrm{z}$ drugiej natomiast ze świadomej polityki UNRRA ${ }^{23}$, której przyczyny zostaną omówione w dalszej części artykułu. W pierwszym okresie istnienia obozów bujnie rozwijała się również prasa obozowa, obejmująca szeroką gamę publikacji - od jednodniówek, przez biuletyny aż po dzienniki. Żywotność poszczególnych tytułów była różna, jednakże z racji linii politycznej czasopism, która często nie była zgodna z celami wyznaczonymi przez władze okupacyjne pragnące repatriować wszystkich dipisów, publikacje te były często cenzurowane ${ }^{24}$. Zamykanie obozowych czasopism krytykujących rząd w Warszawie było o tyle dziwne, że o nowych władzach nad Wisłą negatywnie wypowiadała się prasa brytyjska i amerykańska ${ }^{25}$. Stało się to również przedmiotem krytyki ze strony „Dziennika”. Równie negatywnie oceniany był przez redaktorów częsty brak dostępu do radia - nawet brytyjskiego; skutkowało to sprzeciwem wobec kroków podejmowanych przez UNRRA. Polscy dipisi nie znali motywacji pewnych kroków podejmowanych przez władze okupacyjne, co wpływało na realizację poszczególnych zarząazeń władz obozowych. Jak zaznaczali redaktorzy gazety, informowanie na przykład o tym, że braki w żywności czy odzieży są spowodowane ogólnoeuropejskimi problemami, przekładałoby się na większe zrozumienie wśród dipisów ${ }^{26}$. Przekazanie takiej informacji przyczyniłoby się do uspokojenia ich. W materii dostępu do polskich dzieł kultury dużą rolę odegrał sam „Dziennik”, którego

${ }^{20}$ DPDŻ, Obozy polskie bez książek, radia, gazet, 9 VI 1945.

${ }^{21}$ Ibidem.

22 J. Łaptos, op. cit., s. 275; A. Łakomy, Metody rozpowszechniania i promocji polskiej ksiażki wśród społeczności dipisowskiej [w:] Kultura ksiażki i prasy polonijnej: dziedzictwo narodowe i światowe, red. M. Kalczyńska, D. Sieradzka, Z. Małecki, Katowice 2009, s. 85.

23 J. Łaptos, op. cit., s. 277-278.

${ }^{24}$ Ibidem, s. 278.

25 Ibidem, s. 305.

${ }^{26}$ DPDŻ, Btędy opieki nad wysiedleńcami, 6 X 1945. 
redakcja regularnie ponawiała apele o dostarczanie na terytorium Niemiec z terenu Wielkiej Brytanii polskich książek czy informowała o organizowanych zbiórkach pieniędzy ${ }^{27}$. Oceniając zatem wymowę artykułów publikowanych na łamach DPDŻ, należy zaznaczyć, że pomimo tego, iż podobnie jak w wypadku warunków obozowych również i w tym zakresie była ona przesadzona, to londyńska gazeta wydatnie przyczyniała się do pomocy rodakom na terytorium byłej Rzeszy, organizując akcje pomocowe.

Trzecim wątkiem życia obozowego na terenie okupowanych Niemiec było porównanie sposobu traktowania przez władze okupacyjne dipisów i Niemców. Wielokrotnie „Dziennik” podkreślał, że Niemcy, naród pokonany, był lepiej traktowany niż dipisi. Z relacji zdanej pismu przez jednego z Polaków wynikało, że bardzo szybko po wkroczeniu wojsk okupacyjnych Niemcy zaczęli odżegnywać się od nazizmu i władz. Ze względu na łagodną okupację - w tym wypadku amerykańską - Niemcy poczuli się pewniej, odnosili się do Amerykanów z życzliwością, a do innych narodowości - z wrogością. W obozach strefy amerykańskiej stosunek do tych dwóch nacji wynikał - jak relacjonował dipis - z osobistych poglądów żołnierzy amerykańskich. Tam, gdzie żołnierz miał pochodzenie niemieckie lub był pod wpływem niemieckich tłumaczek i maszynistek, stosunek do ludności polskiej miał być chłodny, co przekładało się na pewne ograniczenia i trudności sprawiane polskim dipisom. Część Niemców, która była zatrudniona w amerykańskiej administracji, przyczyniała się również do kreowania wśród Amerykanów nieprzychylnego stosunku do Polaków ${ }^{28}$. Prawdą jest, że amerykańscy żołnierze woleli fraternizować się ze schludnymi, zadbanymi autochtonami niż z dotkniętymi wojną, zaniedbanymi dipisami, niezależnie od ich pochodzenia ${ }^{29}$.

Trzeba przyznać, że redakcja „Dziennika” nie bała się również podejmować zagadnień, które niezbyt dobrze świadczyły o części polskich dipisów. Tak było w wypadku polemiki, jaką podjęli dziennikarze po opublikowaniu przez londyńską gazetę „Evening Standard” 17 czerwca 1946 roku artykułu, z którego wynikało, że za 97\% przestępstw dokonywanych w strefie brytyjskiej byli odpowiedzialni Polacy. Informacja ta została sprostowana w kolejnym wydaniu gazety, została jednak podana do publicznej wiadomości przez urzędnika administracji na terenie Niemiec. Redakcja DPDŻ dokonała sprostowania powyższych danych na podstawie nowo otwartej w Londynie wystawie „Germany under Control”. Z drugiej strony dziennikarze przypominali, że przestępczość wśród polskich dipisów jest pięciokrotnie wyższa niż wśród innych narodowości ${ }^{30}$.

Wreszcie ocenie została również poddana sama UNRRA, na której gazeta nie zostawiła suchej nitki. Redakcja „Dziennika” przedstawiała organizację jako skompromitowaną instytucję, która zamiast pomagać - szkodzi dipisom. Krytyka UNRRA przebiegała na kilku płaszczyznach. Po pierwsze, organizacja jawiła się redakcji jako strażnik przymusowej repatriacji, który zmusza Polaków do powrotu do kraju

${ }^{27}$ DPDŻ, Nadsyłajcie książki, 1 I 1947; DPDŻ, O pomoc dla Polaków w Niemczech, 15 XII 1948.

${ }^{28}$ DPDŻ, Jak Amerykanie w Niemczech traktują Niemców, a jak Polaków?, 17 VIII 1945.

${ }^{29}$ J. Ła a to s, op. cit., s. 127.

${ }^{30}$ DPDŻ, Przestępstwa wśród wysiedleńców polskich, 28 VI 1946. 
zniewolonego przez komunistów. Po drugie, UNRRA była dla dziennikarzy londyńskiego czasopisma instytucją, która rozbijała bujne życie kulturalno-edukacyjne, towarzyskie Polaków poprzez przenosiny, łączenie i likwidowanie obozów. Wreszcie organizacja postrzegana była jako komunistyczna agentura. Po trzecie, UNRRA była krytykowana za to, że zmusza dipisów do repatriacji. Przy tym zarzucie pojawia się najważniejsza przyczyna, z której wynika czarny obraz organizacji. W oczach większości polskich dipisów - jak relacjonował „Dziennik” - repatriacja do ojczyzny, zwłaszcza zawładniętej przez komunistów, powinna być wyłącznie dobrowolna, a dipisi, którzy odmówią powrotu do Polski, powinni automatycznie otrzymywać status uchodźcy ${ }^{31}$. Dlatego też wszelkie akcje repatriacyjne podejmowane przez UNRRA, które wraz z kolejnymi miesiącami od zakończenia wojny nasilały się, były postrzegane przez dipisów, uchodźców jako sprzeczne z pierwotnymi celami, do jakich została powołana organizacja. Tymczasem w rzeczywistości było na odwrót. Od początku istnienia UNRRA jej głównym zadaniem była repatriacja, co było podyktowane w głównej mierze względami politycznymi i ekonomicznymi. Za możliwych do repatriacji uznano obywateli tych krajów, które formalnie były niepodległe, ale które znajdowały się w radzieckiej strefie wpływów. W praktyce dotyczyło to dipisów polskich i części jugosłowiańskich. W rzeczywistości, a nie tak jak chcieli to widzieć dziennikarze, dipisi, którzy nie zamierzali wracać do Polski, nie byli do tego fizycznie przymuszani. UNRRA próbowała natomiast wszelkimi środkami nakłonić ich do powrotu, tak że repatriacja stała się pewnego rodzaju krucjatą, obsesją ${ }^{32}$. Stąd też kroki mające na celu zachęcić Polaków do repatriacji - na przykład „Akcja Marchewka" ${ }^{33}$, jak również wszelki działania, które miały zniechęcić ich do pozostania na terenie okupowanych Niemiec, na przykład ograniczenia w aktywności kulturalnej dipisów, przenoszenie obozów, co dezorganizowało życie displaced persons.

Co pewien czas na łamach „Dziennika” pojawiały się również zarzuty co do samej organizacji, że jest sowiecką siatką szpiegowską. Miały potwierdzać to między innymi doniesienia o aresztowaniu sowieckich agentów działających w UNRRA ${ }^{34}$. Trzeba przyznać, że zarzuty o szpiegostwo nie były wymysłem ${ }^{35}$. Sprzyjanie repatriacji było z kolei wiązane z poparciem dla rządów komunistycznych w Europie Środkowo-Wschodniej, a to już prowadziło do tezy, że szeregi organizacji były infiltrowane przez komunistycznych agentów ${ }^{36}$. Wszelkie argumenty natury politycznej miały służyć dyskredytacji UNRRA ${ }^{37}$.

Równie zaciekle na łamach gazety atakowane były władze UNRRA, a w szczególności dyrektor generalny Fiorello la Guardia, który zdawał się lekceważyć przyczyny

${ }^{31}$ DPDŻ, O przyszłości uchodźców i wysiedleńców polskich, 13 V 1946.

32 J. Łaptos, op. cit., s. 283-284.

33 J. Chw as ty k-Kow alczyk, Londyński „Dziennik Polski i Dziennik Żolnierza”..., s. 115.

${ }^{34}$ DPDŻ, Repatriację 450 tysięcy wysiedleńców zamierza przeprowadzić La Guardia, 22 VIII 1946.

${ }_{35}$ Por.: K. Kowalski, Plan Marshalla, Uwarunkowania i skutki gospodarczo-polityczne, Łódź 2014, s. 59; J. Haynes, H. Klehr, Venona: Decoding Soviet Espionage in America, New HavenLondon 1999, s. 204.

${ }^{36}$ DPDŻ, UNRRA wcią̇ przekracza swoje kompetencje, 3 IV 1947.

37 J. Łaptos, op. cit., s. 308. 
polityczne, dla których dipisi nie chcieli wracać do swoich krajów ${ }^{38}$, a część jego wypowiedzi była brana przez dipisów za sprzyjanie Moskwie ${ }^{39}$. Dyskredytacji dyrektora miały również służyć informacje o tym, iż la Guardia spotkał się z Bolesławem Bierutem czy Josipem Titą ${ }^{40}$, co wynikało jednak po prostu z obowiązków, które musiał wypełnić. La Guardia miał również lekceważyć sygnały o działalności sowieckich szpiegów w szeregach organizacji ${ }^{41}$.

Zarysowany powyżej obraz jest wyolbrzymiony, biorąc pod uwagę ogromny wysiłek, jaki UNRRA wykonała w kwestii opieki nad dipisami, i skalę, na jaką musiała działać. Nie należy też bagatelizować losu dipisów i uchodźców, którzy po koszmarze okupacji oczekiwali na lepsze życie. Dowodów na to, że sytuacja nie była aż tak dramatyczna, jak rysował ją DPDŻ, dostarczają - jak pisze Józef Łaptos - chociażby fotografie $\mathrm{z}$ tamtego okresu, na których widać uśmiechniętych i zadbanych dipisów na polskich uroczystościach kościelnych i rodzinnych ${ }^{42}$. Główną przyczyną tak odmiennego postrzegania warunków życia dipisów było niezrozumienie lub brak informacji o tym, jaką rolę UNRRA miała odegrać w przypadku uchodźców i displaced persons. O tym, że akcja repatriacyjna dipisów nie była - dla większości z nich przymusowa, świadczy fakt, że do Polski powróciło ostatecznie $80 \%$ z milionowej rzeszy polskich dipisów ${ }^{43}$.

Inne podejście miała początkowo redakcja DPDŻ do IRO. Jeszcze w trakcie narodzin organizacji została ona obdarzona pewnym kredytem zaufania, o czym świadczą pozytywne komentarze odnoszące się do kierownictwa IRO. Jednocześnie dziennikarze podkreślali, że aby organizacja mogła zrealizować swoje cele, musi mieć charakter „techniczny”, a nie „polityczny”, jak było w wypadku jej poprzedniczki ${ }^{44}$. Zachwyt dziennikarzy nad IRO nie trwał jednak długo. Już w czerwcu 1947 roku, a więc prawie pół roku po jej powstaniu, negatywnie oceniano wypowiedzi Artura Altmayera, sekretarza komitetu wykonawczego IRO, który wielokrotnie oznajmiał, że jednym z celów organizacji jest skłonienie jak największej liczby uchodźców do repatriacji ${ }^{45}$. Natomiast we wrześniu 1948 roku redakcja gazety pisała wprost, że organizacja idzie w ślady UNRRA, jeśli chodzi o politykę repatriacyjną ${ }^{46}$. Rozpoczęcie działalności przez IRO oznaczało jednak zakończenie repatriacji masowej, a także przesunięcie punktu ciężkości polityki względem dipisów, w tym również władz wojskowych, na rzecz osiedlenia ${ }^{47}$.

Redakcja DPDŻ była również żywo zainteresowana wszelkimi działaniami opinii międzynarodowej dotyczącymi rozwiązania problemów dipisów i uchodźców.

${ }^{38}$ Ibidem, s. 289.

39 DPDŻ, Znowu La Guardia, 13 IX 1946.

40 DPDŻ, Repatriację 450 tysięcy wysiedleńców zamierza przeprowadzić La Guardia, 22 VIII 1946.

${ }^{41}$ DPDŻ, La Guardia chce zmusić wysiedleńców do powrotu, 30 VIII 1946.

42 J. Łaptos, op. cit., s. 218.

${ }^{43}$ K. Kersten, op. cit., s. 44.

44 DPDŻ, Organizacja praktycznej pomocy uchodźcom, 29 V 1947; DPDŻ, I.R.O. przejmuje opieke nad uchodźcami, 5 VI 1947.

${ }^{45}$ DPDŻ, IRO wobec projektów przymusowej repatriacji, 13 VI 1947.

46 DPDŻ, IRO naktania uchodźców do repatriacji, 25 IX 1948.

${ }^{47}$ K. Kersten, op. cit., s. 26. 
Jednym z najczęstszych tematów w tej dziedzinie były spory, jakie wybuchały pomiędzy Zachodem a ZSRR i jego satelitami, dotyczące pomocy displaced persons. Delegacja sowiecka w lutym 1946 roku na forum Organizacji Narodów Zjednoczonych forsowała koncepcję, zgodnie z którą pomoc dipisom, jeśli odmówiliby oni powrotu do kraju, miałaby być uzależniona od zgody kraju ojczystego. Ostatecznie projekt rezolucji Zgromadzenia ONZ w sprawie pomocy uchodźcom, przedstawiony na posiedzeniu Komitetu do spraw Humanitarnych i Społecznych, w kształcie proponowanym przez Moskwę został odrzucony, co redakcja gazety skomentowała w dosyć patetyczny sposób: „Ostatecznie okazało się, że nie ma możliwości kompromisu między dwoma światami o tak różnych zasadach politycznych i moralnych"48.

Redakcja uwypuklała również kolejne rozbieżności pomiędzy blokiem wschodnim a państwami Zachodu w kwestii dipisów i uchodźców, co było widoczne zwłaszcza w relacjach z międzynarodowej konferencji (Special Committee on Refugees and Displaced Persons) poświęconej zagadnieniu utworzenia organizacji opiekującej się uchodźcami, która odbyła się między kwietniem a lipcem 1946 roku w Londynie ${ }^{49}$. W czasie jej obrad delegat sowiecki podkreślał, że nowa organizacja powinna istnieć tylko do czasu, gdy większość dipisów powróci do krajów ojczystych ${ }^{50}$, co wpisywało się w sowieckie dążenia do tego, aby wszyscy jej przedwojenni obywatele powrócili na terytorium ZSRR. Dziennikarze negatywnie oceniali wyniki londyńskiej konferencji, według której późniejsza IRO miała być organizacją całkowicie niezależną od ONZ ${ }^{51}$.

DPDŻ na bieżąco relacjonował negocjacje dotyczące powstania nowej organizacji, pokazując kolejne sprzeczności pomiędzy Zachodem i Wschodem i uderzając w obie strony sporu. Redakcja londyńskiego pisma, informując o dyskusjach nad projektem statutu IRO, chwaliła odpowiedź Eleonory Roosevelt na sowieckie żądania zakazu propagandy w obozach przeciw krajom pochodzenia. Wdowa po amerykańskim prezydencie odparła, że USA również tam, tak jak wszędzie, bronią wolności opinii. Autor artykułu skomentował wypowiedź Roosevelt następująco: „Jaka szkoda, że taka przepaść dzieli postępowanie władz amerykańskich w Niemczech od haseł bronionych przez p. Roosevelt w Nowym Jorku!" 52 . To rozczarowanie odnosiło się zapewne do postępowania amerykańskich władz obozowych i okupacyjnych ograniczających życie kulturalne dipisów; dotyczyło także nakłaniania do repatriacji.

Wszechstronnej krytyce na łamach „Dziennika” zostały poddane nowe, ,warszawskie” władze Polski. „Dziennik” z nieufnością podchodził do wszelkich zachęt powrotu do kraju czy ofert pomocy dipisom formułowanych przez władze Polski Ludowej. Przykładem takiego zachowania jest krytyka oferty pomocy konsularnej

${ }^{48}$ Cytat: DPDŻ, Klęska bloku sowieckiego w sprawie uchodźców, 9 II 1946; DPDŻ, Udaremniono zamach na wolność uchodźców, 11 II 1946; DPDŻ, Wnioski sowieckie w sprawie uchodźców odrzucone, 14 II 1946.

49 Refugees and Displaced Persons Report of Third Committee, https://www.unhcr.org/protection/ historical/3ae68bee8/refugees-displaced-persons-report-third-committee.html [dostęp: 29 IV 2020 r.].

${ }^{50}$ DPDŻ, Sowiety nie chca opieki nad uchodźcami, 26 IV 1946.

${ }^{51}$ DPDŻ, Fiasko konferencji dla spraw uchodźców, 4 V 1946.

52 DPDŻ, Pani Roosevelt w obronie uchodźców, 11 XI 1946. 
wszystkich dipisom, którzy nie zdecydowaliby się na powrót do kraju. Jako dowód na fałszywość tej propozycji gazeta przytoczyła przypadek polskich Żydów, którzy pragnęli emigrować do Palestyny. W czasie półlegalnej migracji z Polski trafili oni do Francji, gdzie zażądano od nich dokumentów tożsamości. Osoby te udały się więc do konsulatu, gdzie odmówiono im przyznania dokumentów, powołując się na trudności w potwierdzeniu ich obywatelstwa, między innymi z powodu utraty archiwaliów $\mathrm{w}$ czasie wojny ${ }^{53}$. Być może propozycja władz warszawskich skierowana do dipisów faktycznie miała na celu roztoczenie nad dipisami jakiejś formy kontroli, co jednak nie oznaczało chęci pomocy.

Negatywną opinię dziennik wystawił również delegatowi Tymczasowego Rządu Jedności Narodowej do UNRRA, Edwardowi Szturm de Sztrem. Według dziennikarzy reprezentował on interesy Moskwy, a nie polskich dipisów. Na wspomnianej już konferencji w kwietniu 1946 roku polski delegat ocenił, że powołanie organizacji zajmującej się opieką nad uchodźcami, która będzie niezależna od ONZ, jest dla uchodźców lepszym rozwiązaniem. Opinia ta jednoznacznie została odebrana przed DPDŻ jako przejaw uległości Warszawy wobec Moskwy, która forsowała takie rozwiązanie ${ }^{54}$.

„Dziennik” nie poprzestawał jednak na krytyce przymusowej repatriacji, ale równolegle informował o możliwościach emigracji. Państwami, którym redaktorzy gazety poświęcili najwięcej miejsca, były Wielka Brytania i Stany Zjednoczone. Szczególnie ten drugi kraj jawił się dziennikarzom jako ziemia obiecana dipisów ${ }^{55}$. Redakcja informowała o kolejnych decyzjach władz USA dotyczących możliwości przyjęcia uchodźców ${ }^{56}$, a także o niemal nieograniczonych możliwościach zarobkowych, między innymi w rolnictwie i budownictwie amerykańskim ${ }^{57}$. Być może Stany Zjednoczone robiły na dziennikarzach wrażenie nie tylko ze względu na warunki życia, ale też znaczące zmiany, jakie zaszły w tamtejszym prawie, w tym uchwalenie przez Kongres tak zwanego Displaced Persons Act, który to pozwalał na odejście od niezwykle rygorystycznych amerykańskich zasad imigracyjnych ${ }^{58}$.

„Dziennik”, mimo powszechnej krytyki UNRRA, przestrzegał również polskich dipisów i uchodźców przed podejmowaniem lekkomyślnych kroków - na przykład „dzikiej” emigracji, w szczególności do Afryki i krajów Ameryki Łacińskiej, w realiach których wielu Polaków się nie odnajdowało. Gazeta ganiła również część uchodźców za bezczynność, także w czasie wojny, co później mogło przekładać się na tytułowe „,problemy uchodźców”, jak było w przypadku emigrantów pochodzenia inteligenckiego na Bliskim Wschodzie, za co odpowiadali polscy delegaci. W czasie wojny uchodźcy ci otrzymywali zasiłki, ale poprzestali na organizowaniu

${ }^{53}$ DPDŻ, Uchodźcy i paszporty, 21 X 1946.

${ }^{54}$ DPDŻ, Fiasko konferencji dla spraw uchodźców, 4 V 1946.

${ }^{5}$ DPDŻ, Tysiace uchodźców znajda pracę w USA na roli, rzemiośle i budownictwie, 25 IX 1948.

56 DPDŻ, Debata o uchodźcach w Senacie USA, 27 V 1948; DPDŻ, Ustawa o dopuszczeniu 205.000 D.P. do USA ostatecznie uchwalona przez Kongres, 21 VI 1948; DPDŻ, 50. tys. uchodźców w ciagu roku do USA, 1 VII 1948.

${ }^{57}$ DPDŻ, Tysiace uchodźców znajda pracę w USA, 28 IX 1948.

${ }^{58}$ K. Kersten, op. cit., s. 43. 
różnorodnych odczytów, spotkań, podczas gdy uchodźcy innych narodowości zdobywali kwalifikacje zawodowe, które stały się przydatne po zakończeniu działań wojennych.

Podsumowując, należy powiedzieć, że „Dziennik Polski i Dziennik Żołnierza” uwypukla przede wszystkim negatywne aspekty życia dipisów w obozach na terenie okupowanych Niemiec. Obraz ten daleki jest jednak od rzeczywistości - choć warunki w obozach nie mogły w pełni satysfakcjonować ludzi szczególnie dotkniętych przez wojnę, to w tymczasowych domach dipisów dokonało się przywrócenie godności tym osobom. Gazeta piętnowała również działania organizacji, która ponosiła, w opinii dziennikarzy, odpowiedzialność za ten stan rzeczy. UNRRA została ówcześnie dosyć niesprawiedliwie oceniona. Jednocześnie dziennikarze byli w pewnym stopniu wyrazicielami rzeczywistych nastrojów wśród dipisów i uchodźców. Część uwag poczynionych na łamach londyńskiego czasopisma względem władz okupacyjnych Niemiec i UNRRA była rzeczowa, a ich uwzględnienie przyczyniłoby się do zmiany stosunków pomiędzy dipisami a władzami obozowymi.

\section{BIBLIOGRAFIA}

\section{Źródła}

„Dziennik Polski i Dziennik Żołnierza”

Refugees and Displaced Persons Report of Third Committee, 13 XII 1946 r., https://www. unhcr.org/protection/historical/3ae68bee8/refugees-displaced-persons-report-third-committee.html [dostęp: 29 IV 2020 r.].

\section{Opracowania}

Chwastyk-Kowalczyk J., Katyń, dipisi, PKPR na łamach polskich czasopism uchodźczych, Kielce 2011.

Chwastyk-Kowalczyk J., Londyński „Dziennik Polski i Dziennik Żotnierza” 1944 1989. Gazeta codzienna jako środek przekazu komunikatów kulturowych, Kielce 2008.

Haynes J., Klehr H., Venona: Decoding Soviet Espionage in America, New HavenLondon 1999.

Kersten K., Repatriacja Polaków z b. Rzeszy Niemieckiej po drugiej wojnie światowej, cz. 2: Polska Ludowa, t. VII, 1968, s. 3-44.

Kowalski K., Plan Marshalla. Uwarunkowania i skutki gospodarczo-polityczne, Łódź 2014.

Łako my A., Metody rozpowszechniania i promocji polskiej książi wśród społeczności dipisowskiej [w:] Kultura ksiązki i prasy polonijnej: dziedzictwo narodowe i światowe, red. M. Kalczyńska, D. Si eradzka, Z. Małecki, Katowice 2009, s. 84-93.

Ła p tos J., Humanitaryzm i polityka. Pomoc UNRRA dla Polski i polskich uchodźców w latach 1944-1947, Kraków 2018. 
Le mbek A., We s s els K., Wyzwoleni, ale nie wolni. Polskie miasto w okupowanych Niemczech, thum. B. Ostrowska, Warszawa 2006.

Sękowski P. Activity of the International Community in Europe after the Second World War within the Scope of the International Refugee Organization as a Model of the Aid Action Towards Refugees, „Securitologia” 2017, no. 1, s. 119-139.

Żak J., Polscy dipisi w zachodnich strefach okupacyjnych Niemiec na łamach polskiej prasy emigracyjnej (1945-1947), „Naukowy Przegląd Dziennikarski”, 2017, nr 3, s. 95-127. 